\title{
Use of ergonomic principles in manual order pic king systems
}

\author{
Nina Labus ${ }^{1}$, Brigita Gajšek ${ }^{1}$ \\ IUniversity of Ma ribor/Fa culty of Logistics, Celje, Slovenia
}

\begin{abstract}
Successful companies are continually striving to streamline costs and optimize processes, enabling them to grow progress, develop and ensure competitiveness on the market. A large part of the costs arises in warehouses, where up to $55 \%$ of total costs are generated by order-picking, which makes it important and interesting in terms of research. The paper explores "picker to part" order-picking concept, which enables flexible work and is the optimal choice for most companies. The concept is associated with a high level of work-related injuries and work-related illnesses. Work requires physical efforts resulting from handling heavy goods, performing repetitive movements and using manipulative means. Human as the main actor of the concept affects the costs caused by picking and the quality of work done, which depends on technological support, physically and psychologically capable and motivated people. Due to the high costs of senvice, the focus on time planning and productivity increases. Contrary, the lack of attention is paid to the working conditions and the health status of the pickers. To overcome this gab, a review of scientific and professional literature on ergonomic principles in picking concept »picker to part« was camied out, followed by a quantitative survey of ergonomic properties in warehousing activities. Results revealed that more than $60 \%$ of the surveyed order-pic kers associate problems with health with the characteristics of work, about $24 \%$ of them associate health problems with the use of a particular means of tansport, and all agree that provided measures to reduce physical effort and greater support of technologies influence on increased speed of work and better health status of order-pic kers.
\end{abstract}

Key words - injuries, picker-to-part, ergonomics, picking, productivity, costs

\section{INTRODUCTION}

The complete technologic al sophistic ation of the warehouse enables the optimization of processes with automation, where human performs a minimal, urgent part of the process. However, studies show that $80 \%$ of the work in picking systems and warehouses is still handled by hand, where pickers walk or collect goods through manipula tive means (De Koster et al., 2007; Na polita no, 2012; Grosse, Glock \& Neumann, 2015). This fact proves that the picking process is labour intensive with a high level of human work. At the same time, picking is the most costly process that makes more than half of total costs in storage (Tompkins et al., 2010; Ric hards, 2012; Grosse, Glock \& Neumann, 2015). Consequently, it is understandable that employers and researchers are striving to find ways to achieve a greater number of picks per time frame. These efforts clearly do not affect the reduction in musculoskeletal disorders that a re not decreasing over the years and a re signific antly higher in logistics than in other sectors. As stated by Grilec (2015): »According to the US Office of Labour Statistics, the proportion of musculoskeletal disorders and accidents at work throughout the private sector is 33.5 cases per 10.000 workers. Of this, in agric ulture, forestry and fishing, the maximum of 41.5 cases per 10.000 workers are reached. In the meantime, in the service sector, especially in transport and storage, the level of MSD and injuries rises to 80,3 cases per 10.000 workers. If we compare the level of damage in the entire private sectorand in the area of transport and storage, we can quickly assume that the damage is twice as high in the latter. Furthemore, we can say from the above that there a re certa inly many possibilities and room for improvement in this area in an ergonomic sense. Ergonomic is a science that generally connects human and the working environment in order to create optimal working conditions for a particular worker, thus enabling the worker to do his job well.

The next indic ator that highlights the importance of dealing with workers is a demographic picture that indicates that the population is aging. »The share of the work contingent (20 - 64 years) is projected to decline in the future from $64 \%$ this year to $59 \%$ in 2024 and to $56 \%$ in 2034 . If we 
compare these two age groups, we find out that on 100 people in the labour contingent are currently around 27 people aged 65 and over. Average age of the population is expected to rise from 42 to 46 years in the next two decades. «(Sambt, 2014). Companies must, not only because of their responsibility to society, but also due to long-tem goals, integrate their employees into strategic planning and take care of the operational capability of their staff. Therefore, it makes sense for companies foc us a lso on reduction of the physic al and mental burden on employees and not solely to rise of productivity.

The paper contributes to the understanding of order-pickers' health problems researching correlations between the degree of intensity of the observed type of health problem and:

(1) frequency of certa in movements,

(2) type of means of transport used.

Correlations were researched by the survey based on 126 valid questionna ire, which were retumed from order-pickers in several logistic companies around Slovenia. The research contributes to understanding the importance to use ergonomic principles in the order-picking process and provides a guide for further research.

\section{PRODUCTIVITY AND ERG ONOMIC PRINCIPLESIN MANUALORDER-PIC KING}

Picking is a process that is regardless of the technological sophistication of the warehouse physically demanding. It is one of the essential processes of intra-logistic s where the order-picker prepares goods according to customer orders. The picking process "picker-to-parts" is considered as the most labour-intensive process in warehouse, resulting in up to $55 \%$ of the total costs of storing goods, which represents the potential and challenge to reduce costs. The costs are caused by the traveling, searching, picking and set-up. Approximately $55 \%$ of the total order-pic king time is spent for traveling (Tompkins et al., 2010). Due to the large impact of tra veling on the total costs, different authors identify that the determination of the shortest route is the key goal of optimization efforts and the most common way to increase productivity. Warehouses are seen in the eyes of owners as cost centres that combine high capital and require a high level of human work that is physically tiring. Although automation seems to be the right solution, manual work rema ins and the morbidity of employees is increasing in relation to order industries. The important competitive advantage of manufacturing companies is seen mostly in the productivity of employees and the organization of the process (Hompel et. al., 2011; Günthner et al., 2014) while good working conditions are still neglected.

Order-picking system »pic ker to part «is flexible and requires minimal investment costs compared to automated solutions. Productivity in such systems largely depends on order-pic kers who camy out risky work such as raising or lowering loads by twisting or bending the upper part of the body. The a vailability of a worker depends on the number and severity of injuries, just as the ava ila bility of the machine depends on the number and severity of defects. The productivity of order-pickers is closely linked to fatigue, which can be reduced by rest. Productivity, injuries and fatigue are affected by ergonomic conditions. Musculoskeletal disorders are the most reported causes for absence from work and account for over $52 \%$ of all work-related illnesses and more than $2 \%$ of the gross national product in the European Union (Schneider \& Irastorza, 2010; Grosse et al., 2015), where low back disorders are the most costly of the musculoskeletal disorders (Marras, Da-vis, Kirking \& Bertsche, 1999). For this reason and in light of demographic changes and an increasing work lifetime, human factor issues at work have gained importance (Gajšek et al., 2017). This is paralleled by legal initiatives in many countries, which leads to an increase in regulations that enforce occupational safety in logistics (Grosse et al., 2015). However, the changes are very slow and employers are very conservative and insist that improved conditions of work cannot retum fina ncial contributions within a rea sona ble time (Gajšek et al., 2017).

\section{UTERATURE REVIEW}

Chapter presents findings from scientific and professional research in the field of ergonomics in manual order-picking. 
Picking tasks in order to increa se productivity, as well as the separation of production and logistic s activities, led to an increase in the physic al burden on employees. Permanent execution of manual picking tasks increases the pressure on the joints and the spine, especially in the lumbar spine, causing degenerative, pemanent defects. For this reason, the injury of the lumbar spine is known as a recognized occupational injury caused by long-standing upsets, the camying of heavy loads or long-term ac tivities in extreme situa tions (Günthner et al., 2014). Mentioned a ctivities have negative impact on the spinal cord of order-pickers that includes pain, illness, injury, and temporary or permanent incapability for work. Musculoskeletal disorders and injunies of the skeletal system are the ma in causes that employees pemanently or temporarily leave the labour market, followed by a decline in productivity (Goldscheid, 2008; Bokranz \& Landau, 2006; Günthner et al., 2014). Musculoskeletal disorders characterize health problems of muscles, whales, skeletons, cartilage, vascular system and ligaments. Excessive and repetitive tasks in the order-picking process increase the risk for order-pickers who largely suffer from musculoskeletal disorders (Punnett \& Wegman, 2004; Grosse et al., 2015). In 2005, 35 \% of Europeans who suffered from musc uloskeletal disorders worked at work with heavy loads. The most common diseases and / or injuries a re back pain and work-related damage of the upper limbs, known as the »repetitive movements « failure. Treatment and recovery are often ineffective. The result can be permanent inability to work and loss of employment. Absenteeism causes high costs for manufacturing companies, logistics service providers, the national economy and the economy in general (European Agency for Safety and Health at Work, 2010). The economic impact of musculoskeletal disorders, compensations for absenteeism and loss of employment are measured to be up to $2 \%$ of GDP in Europe, which is a p proximately € 23.9 trillion in Gemany a lone (Sc hneider \& Ira storza, 2010; Grosse et al., 2015).

Table 1 summarizes the scientific artic les that are relevant for understanding the disc ussed topic .

Table 1: Scientific papers with summaries

Authors:

Christmanssona, Medbob, Hanssonc, Ohlssonc, Unge Bystromc, Mollerd \& Forsman (2002)

Motmans (2012) Keywords: assembly of goods, pic king, productivity of systems, manual hand ling of goods, case studies, time consumption, physic al work

Full body vibration, forklift driver, running surface, air suspension seat, travel speed
Summary of the artic le:

The research wascamied out on the case of four order-pic kers who were filming during their work. With laboratory equipment, computerized mea surements of muscle strain, work posture and movements were performed. The order-pickers used the carts and the forklift truck without the possibility of personal transport, so they had both hands free for picking. Pickers rated work as physically stressful. The results ind ic a te that the picking was very burdensome for the hands, as the movements were constantly repeated.

Research has shown that the main cause for lower back pain is driving with a forklift truck. $63 \%$ of J a pa nese forklift drivers suffer from pain in the lower part of the spine. Research has also shown that forklift drivers have 2 times more chance of having pain in the lowerpart of the spine than others. Pemanent or prolonged exposure to the overall body to vibration inc reases the risk to damage the lumbar spine and the associated nervous system. 
Battini, Persona \&

Sgarbossa (2014)

sse, Glock \&

Neumann (2015)
Real-time a ssessment of ergonomics, motion detection system, storage processes, industrial applications
Picking, picker to part, warehouse, human factors, ergonomics, literature, content a nalysis

\begin{tabular}{l|l} 
Battini, Ca lza vara, & Picking, human \\
$\begin{array}{l}\text { Persona \& Sgarbossa } \\
\text { (2015) }\end{array}$ & a vaila bility, injuries, \\
ergonomics, cost models
\end{tabular}

Gajšek, Đukić \& Opetuk (2015)
Ergonomics, forklift, musc uloskeletal disorders, lowerback pain
The research is based on an innovative system for evaluating ergonomic effects on the body in real time. The collected data was used to redeploy the warehouse and to train pickers for the proper hand ling of goods in terms of ergonomics. This integration makes it possible to a chieve the final win-win result in tems of optimizing the process with employee productivity and ergonomics. The paper reveals a systematic literature review on order- picking planning models and their relation with order-pic kers. The paper proposes a conceptual fra mework for integrating human factors into planning models of order-pic king ac tivities and hypothesises that doing so improves the performance of an order-pic king system and workers' welfare.

The paperanalyses the impact of ergonomic working conditions on the a vailability and produc tivity of the labour-intensive wa rehouse system with the a im of a ssessing how ergonomic s affect the total cost of systems. Authors have shown that the improvement of ergonomic conditions has an important, positive impact on the total cost of the wa rehouse system.

The paperpresents a review of scientific literature published between 2001 and 2013 on the hea lth problems of forklift drivers. Authors revealed that the most frequent injuries of forklift drivers a re: in $67 \%$ pa in in the lower part of the spine, in $25 \%$ disc omfort, in $17 \%$ problems with the neck and in $8 \%$ back injuries / pain, musculoskeleta I disorders, injuries and pain in the arms.

The literature review revealed that order pickers work is associated with a high level of injuries and work-related illnesses. The problem of the incurred risks in order-picking is the use of various types of technology that require a certa in type of order-pickers' movement and influence with specific factors on the order pickers and their health. It is therefore important to find out the links between the type of means of transport and the health status of the order picker. Companies which want to be competitive on the market within the limits of the available resources and offer the best to the buyers must achieve high productivity of the employees. The literature highlights the impact of ergonomic working conditions on the speed of order pickers' work, which we believe is the one of the most convincing reason for implementation of ergonomic principles into the work processes for the managers. On the basis of the stated reasons and the reviewed literature, we posed 3 theses presented in the next chapter.

\section{METHODOLOGY}

An important part of every research work is the detemination of the research problem and the good preparation and implementation of the research. In order to obtain quality and relevant data, we have camied out a systematic overview of scientific and technical literature, which we 
have found with the help of Intemet browsers that access the online scientific joumals such as ScienceDirect, Logistics joumal, research works of universities and other organizations. We rely on recent literature, published after year 2002. We searched papers with key words "ergonomics" and "order-picking". Papers were divided into relevant papers and these, which did not relate to the field of research. With the descriptive method we defined important terms for understanding our research. Using the synthesis method, we summarized the writings of various authors and brought them together and gained general knowledge about the research topic. Using the compilation method, we summarized the scientific and professional findings of various a uthors.

In the second phase of the research included survey, which was conducted to verify 3 theses. Following theses were proposed on the basis of previously described litera ture review:

- There are correlations between the frequency of various types of order pickers' movement and the degree of intensity of the observed type of order pic kers' health problem.

- There are correlations between the type of means of transport used by the order picker and the degree of intensity of the observed type of health problem.

- Order picker's height of rate of the impact of a particular characteristic of his/hers work on his/hers health correlates with his/hers height of rate of the impact of a particular characteristic of his/hers work on the speed of his/hers work.

Three relevant persons tested the content of the questionnaire to make sure that the questionnaire is comprehensive and meaningful. We also tested the comprehensibility of the content of the questionnaire on 3 order pickers who have been working as order picker for more than 5 years. It tumed out that the questionnaire is understandable and meaningful. Data were collected from September 2015 to August 2016. We provided the questionnaires to the order pickers in person. At that time, out of 21 Slovene companies, 126 valid survey questionna ires were collected, of which 119 or $94.4 \%$ from men and 7 or $5.6 \%$ from women. It was important for us to include order pickers who spend more than $80 \%$ of their working hours for order-picking. The obta ined data were copied into the Statistical Product and Service Solutions (SPSS) database. Using the program, descriptive static a nalysis were camied out.

\section{RESULTS}

We verified three theses. For the sake of better transparency, the variables are written in abbreviations in Table 2. Legend of abbreviations is given in Table 5.

Table 2: Correlations between specific health problem and the frequency of specific movement

\begin{tabular}{|c|c|c|c|c|c|c|}
\hline \multicolumn{2}{|c|}{$\begin{array}{l}\text { Way of working } \\
\text { Hea lth problems }\end{array}$} & $\mathrm{C} 1$ & $\mathrm{C} 2$ & $\mathrm{C} 3$ & $\mathrm{C} 4$ & C5 \\
\hline & 3,4,5 v \% & 59.6 & 80.1 & 63,5 & 61.9 & 84.2 \\
\hline D1 & 76.2 & .349 ** & .337 ** & & & $.290 * *$ \\
\hline D2 & 68.2 & $.213 *$ & $.201 *$ & & .232 ** & .351 ** \\
\hline D3 & 63.4 & $.307 * *$ & .321 ** & & & .398 ** \\
\hline D4 & 59.5 & .260 ** & $.280 * *$ & & & .345 ** \\
\hline D5 & 61.9 & .343 ** & $.229 *$ & & & .232 ** \\
\hline D6 & 54.8 & .350 ** & $.218 *$ & & & $.237^{* *}$ \\
\hline D7 & 38.8 & & & & $.248 * *$ & .335 ** \\
\hline D8 & 42.1 & .240 ** & .276 ** & & & \\
\hline D9 & 59.6 & & & $.186 *$ & .320 *k & .319 ** \\
\hline
\end{tabular}

The first verified thesis is:

- There are correlations between specific health problem and the frequency of specific movement.

In Table 2, we present the values of correlations between specific health problems (D1-D9) and the frequency of specific movement (C1-C5). The first thesis can be partly confimed. 
Thesis 1 confims the linear dependence between bilaterally dependent phenomena, indic ated by the coeffic ient of correlation. Correlations a re signific ant for the following relationships:

- intensity of pain in the lower part of the spine (D1) signific antly correlates with the frequency of:

0 lowering the load from the height above the shoulder and head height $(C 1)(T=.349, p<001)$;

0 lifting the load from the height below the knee height (C2) $(T=.337, p<001)$;

0 walking between the places from which the goods are taken (C5) $(T=.290, p<001)$.

- intensity of pain in the neck part (D2) signific a ntly correlates with the frequency of:

0 lifting the load of the height above the shoulder height $(C 1)(T=.213, p<005)$;

0 lowering the load lifting from the height below the knee height (C2) $(T=.201, p<005)$;

0 entering the forklift (C4) $(\mathrm{T}=.232, \mathrm{p}<001)$;

o walking between the places from whic $h$ the goods a re taken $(C 5)(\tau=.351, p<001)$.

- intensity of shoulder pain (D3) correlates with the frequency of:

0 lowering the load from the height above the shoulder and head height $(C 1)(\tau=.307, p<001)$;

0 lifting the load from the height below the knee height (C2) $(T=.321, p<001)$;

0 walking between the places from which the goods are taken (C5) $(T=.398, p<001)$.

- musc le pain intensity (D4) correlates with frequency of:

0 lowering of the load from the height above the shoulder height (C1) $(T=.260, p<001)$;

0 lifting of the load from the height below the knee height (C2) $(\tau=.280, p<001)$;

0 walking between the places from which the goods are taken (C5) $(\tau=.345, p<001)$.

- intensity of pain in the leg muscles (D5) comelates with the frequency of:

0 lowering of the load from the height above the shoulder height (C1) $(T=.343, p<001)$;

0 lifting the load from the height below the knee height (C2) $(T=.229, p<005)$;

0 walking between the places from which the goods are taken (C5) $(\tau=.232, p<001)$.

- intensity of pain in the wrists (D6) correlates with the frequency of:

0 lowering of the load from the height above the shoulder height ( $C 1)(\tau=.350, p<001)$;

0 lifting the load from the height below the knee height $(C 2)(T=.218, p<005)$ :

0 walking between the places from which the goods a re taken (C5) $(\tau=.237, p<001)$.

- intensity of worsened vision (D7) correlates with the frequency of:

0 entering the forklift (C4) $(T=248, p<001)$;

0 walking between the places from which the goods are taken (C5) ( $\mathrm{T}=.335, \mathrm{p}<001$ ).

- intensity of swelling of the legs (D8) correlates with the frequency of:

0 lowering the load from the height above the shoulder height (C1) $(\tau=.240, p<001)$;

0 lifting the load from the height below the knee height (C2) $(T=.276, p<001)$.

- intensity of mental fatigue (D9) correlates with frequency:

o rearward driving (C3) $(\mathrm{T}=.186, \mathrm{p}<005)$;

0 entering the forklift (C4) $(\mathrm{T}=.320, \mathrm{p}<001)$;

0 walking between the places from which the goods a re taken (C5) $(\mathrm{T}=.319, \mathrm{p}<001)$.

The second verified Thesis is:

- There are correlations between the type of means of transport used by the order picker and the degree of intensity of the observed type of health problem.

Table 3 presents the correlations between specific health problems (D1-D9) and the type of mean of transport, which is used by specific order-picker (A1-A8). The second thesis can be partly confimed.

Table 3: Correlations between health problems and the types of mean of transport

\begin{tabular}{|c|c|c|c|c|c|c|c|c|c|}
\hline \multicolumn{2}{|c|}{$\begin{array}{l}\text { Means of } \\
\text { transport }\end{array}$} & Al & $\mathrm{A} 2$ & A3 & A4 & A5 & A6 & A7 & A8 \\
\hline & $3,4,5 \vee \%$ & 39.7 & 34.1 & 50.7 & 45.2 & 50.9 & 11.1 & 18.2 & 8 \\
\hline D1 & 76.2 & .417 ** & & & & $.185^{*}$ & $-.223 *$ & & -.248 ** \\
\hline
\end{tabular}




\begin{tabular}{|c|c|c|c|c|c|c|}
\hline D2 & 68.2 & $.374^{* *}$ & & & & \\
\hline D3 & 63.4 & $.340 * *$ & & & & $-.197 *$ \\
\hline D4 & 59.5 & .370 ** & & & & $-.200 *$ \\
\hline D5 & 61.9 & .318 ** & & & & \\
\hline D6 & 54.8 & $.224 *$ & & & $-.200 *$ & \\
\hline D7 & 38.8 & $.304^{* *}$ & & & & \\
\hline D8 & 42.1 & $.310 * *$ & $.192 *$ & & & \\
\hline D9 & 59.6 & $.316 * *$ & & $-.221 *$ & & \\
\hline
\end{tabular}

Legend: ** - Signific a nt c orrela tion $p \varangle 0.001, *$ - Signific a nt correla tion $p \varangle 0.005$

The sec ond Thesis can be partly confirmed. Correlations are signific a nt for following rela tionships:

- intensity of lower back pain (D1) correlates with the following types of used transportation technology:

ogoods are caried in the hands (A1) $(T=.417, p<001)$;

o pallet truck with possibility of personal transport (A5) $(\mathrm{T}=.185, \mathrm{p}<005)$;

o pallet truck with possibility of lifting the order picker (A6) $(T=-.223, p<005)$;

o order pic ker forklift (A8) $(\mathrm{T}=-\mathbf{2 4 8 ,} \mathrm{p}<005)$.

- the intensity of pain in the neck part (D2) correlates with camying goods in hands (A1) $(T=.374$, $\mathrm{p}<001$ );

- intensity of pain in shoulders (D3) correlates with the following types of used transportation technology:

o goods are camied in the hands $(A 1)(T=.340, p<001)$;

o order picker forklift (A8) ( $\mathrm{T}=-.197, \mathrm{p}<005)$.

- intensity of muscle pain in hands (D4)correlates with the following types of used transportation technology:

o goods a re carried in the hands $(A 1)(T=.370, p<001)$;

o order picker forklift (A8) $(T=.200, p<005)$.

- intensity of musc le pain in legs (D5) correlates with camying goods in hands (A1) $(\tau=.318, p<001)$.

- intensity of pain in wrists (D6) comelates with the following types of used transportation technology:

o goods a re carried in the hands (A1) $(T=.224, p<005)$;

o pallet truck with possibility of lifting the order picker $(A 6)(T=-.200, p<005)$.

- intensity of decrea sed vision (D7) correlates with camying goods in hands (A1) $(\tau=.304, p<001)$.

- intensity of swelling of legs (D8) correlates with the following types of used transportation technology:

ogoods are carried in the hands $(A 1)(T=.310, p<001)$;

otrolley (A2) $(\mathrm{T}=.192, \mathrm{p}<005)$.

- intensity of mental fatigue correlates with the following types of used transportation technology:

o goods are camied in the hands (A1) $(T=.316, p<001)$;

o hand pallet truck $(A 3)(T=-.221, p<005)$.

The third verified Thesis is:

- Order picker's height of rate of the impact of a particular characteristic of his/hers work on his/ hers health correlates with his/hers height of rate of the impact of a particular characteristic of his/ hers work on the speed of his/hers work.

Table 4 shows correlations between impacts on work speed (F1-F7) and impacts on order picker's health (E1-E7). The thesis 3 can be confimed. Correlations are observed for all proposed relationships. 
Table 4: Correlations between impacts on work speed and impacts on order picker's health impacts on order pic ker's health

\begin{tabular}{|l|l|l|l|l|l|l|l|l|}
\hline & & E1 & E2 & E3 & E4 & E5 & E6 & E7 \\
\hline Impacts on work speed & & & & & & & & \\
\hline F1 & $3,4,5 \vee \%$ & 68.3 & 74.6 & 60.3 & 65.9 & 75.3 & 74.6 & 81.7 \\
\hline F2 & 70.6 & $.508^{* *}$ & & & & & \\
\hline F3 & 75.4 & $.566^{* *}$ & & & & \\
\hline F4 & 68.2 & & & $.413^{* *}$ & & & \\
\hline F5 & 68.3 & & & & $.610^{* *}$ & & & \\
\hline F6 & 75.4 & & & & & $.658^{* *}$ & & \\
\hline F7 & 81.8 & & & & & & $.560^{* *}$ \\
\hline
\end{tabular}

Legend: ** - signific a nt correlation $p<001, *$ - signific a nt correlation $p<005$

Table 4 presents correlations between impacts on work speed (F1-F7) and impacts on order picker's health (E1-E7). We note that respondents have identified all options with more than $60 \%$ agreeing on the impact of proposed measures on work speed and order picker's health. Measures include different ways of physical effort reduction and use of different technic al or technological support. When examining Table 4 diagonally, we notice that these measures, according to order pickers, have a disproportionate effect both on the work speed and on the order picker's health status. It can be concluded that order pickers agree that reduction of needed physical effort, better technical equipment and use of technological solutions reduce health risks and increase orderpicking productivity.

Correla tions a re signific ant for following relationships:

- measure 1: reduced amount of work that requires stretc hing above shoulder; impact on health (E1) correlates with impact on work speed $(F 1)(T=.508, p<001)$;

- measure 2: reduced a mount of work that requires lifting from height under the knees; impact on health (E2) correlates with impact on work speed (F2) $(\mathrm{T}=.566, \mathrm{p}<001)$;

- measure 3: use of pallet truck with mounted aerial platform for employee for order picking in the first floor of the storage rack; impact on health (E3) correlates with impact on work speed (F3) $(\mathrm{T}=.413, \mathrm{p}<001)$;

- measure 4: use of pallet truck with option of lifting the pallet to the height of goods disposal; impact on health (E4) correlates with impact on work speed (F4) $(T=.610, p<001)$;

- measure 5: use of pallet truck with possibility of personal transport; impact on health (E5)

correlates with impact on work speed (F5) ( $T=.658, \mathrm{p}<001)$;

- measure 6: use of barcode or RFID tags reader / teminal / smartphone; impact on health (E6) correlates with impact on work speed (F6) ( $\mathrm{T}=.560, \mathrm{p}<001)$;

- measure 7: introduction of automation in the sense of "goods-to-order picker"; impact on health

(E7) correlates with impact on work speed (F7) $(\mathrm{T}=.763, \mathrm{p}<001)$.

Table 5: Legend of abbreviations

Variable Legend

Transport means 


\begin{tabular}{|c|c|}
\hline A1 & goodsare camed in the hands \\
\hline A2 & use of cart \\
\hline A3 & use of hand pallet truck \\
\hline A4 & use of elec tric pallet truck without possibility of personal transport \\
\hline A5 & use of pallet truck with possibility of personal transport \\
\hline A6 & use of forklift with lifting platform for pic king on $1^{\text {st }}$ floor shelves \\
\hline A7 & $\begin{array}{l}\text { use of forklift with a bility to adjust the height of the pallet on which goods } \\
\text { are placed }\end{array}$ \\
\hline A8 & use of order picking forklift \\
\hline \multicolumn{2}{|c|}{ Characteristic of work } \\
\hline $\mathrm{C} 1$ & lowering loads from the height above the shoulder and head height \\
\hline $\mathrm{C} 2$ & lifting loads from the height below the knee height \\
\hline C3 & looking back while driving forklift \\
\hline C4 & entering in the forklift \\
\hline C5 & walking between places where goodsare taken \\
\hline \multicolumn{2}{|c|}{ Health problems } \\
\hline D1 & lowerbackpain \\
\hline D2 & pain in the neckpart \\
\hline D3 & pain in shoulders \\
\hline D4 & muscle pain in hands \\
\hline D5 & muscle pain in legs \\
\hline D6 & pain in wrists \\
\hline D7 & decreased vision \\
\hline D8 & swelling of legs \\
\hline D9 & mental fatigue \\
\hline \multicolumn{2}{|c|}{$\begin{array}{l}\text { mea sures to improve } \\
\text { order pic ker's health } \\
\text { status }\end{array}$} \\
\hline E1 & reduced a mount of work that requires stretc hing a bove shoulder \\
\hline E2 & reduced amount of work that requires lifting from height under the knees \\
\hline E3 & $\begin{array}{l}\text { use of pallet truck with mounted a erial platform for employee for order } \\
\text { picking in the first floor of the storage rack }\end{array}$ \\
\hline E4 & $\begin{array}{l}\text { use of pallet truck with option of lifting the pallet to the height of goods } \\
\text { disposal }\end{array}$ \\
\hline E5 & use of pallet truck with possibility of personal transport \\
\hline E6 & use of barcode or RFID tags reader / terminal / smartphone \\
\hline E7 & introduction of automation in the sense of "goods-to-order picker" \\
\hline \multicolumn{2}{|c|}{$\begin{array}{l}\text { mea sures to improve } \\
\text { work speed }\end{array}$} \\
\hline F1 & reduced a mount of work that requires stretc hing a bove shoulder \\
\hline $\mathrm{F} 2$ & reduced amount of work that requires lifting from height under the knees \\
\hline F3 & $\begin{array}{l}\text { use of pallet truck with mounted a erial platform for employee for order } \\
\text { picking in the first floor of the storage rack }\end{array}$ \\
\hline F4 & $\begin{array}{l}\text { use of pallet truck with option of lifting the pallet to the height of goods } \\
\text { disposal }\end{array}$ \\
\hline F5 & use of pallet truck with possibility of personal tra nsport \\
\hline F6 & use of barc ode or RFID tags reader / terminal / smartphone \\
\hline F7 & introduction of automation in the sense of "goods-to-order pic ker" \\
\hline
\end{tabular}




\section{FINDINGSAND POSSIBILTIESFOR FURTHER RESERCH}

The thesis 1 assumes the existence of links between the various types of order pickers' movement and the intensity of the observed health problems. The thesis 1 can be confirmed with our empinical research with $60.32 \%$. From $59.6 \%$ of respondents who frequently lower loads from the height above shoulder and head height, $47.6 \%$ of them answered that they were lowering loads that weigh more than $10 \mathrm{~kg}$. From $80.1 \%$ of respondents who frequently raise loads from the height below the knee height, $57.2 \%$ of them raise loads that weigh more than $10 \mathrm{~kg}$. The variables correlate with all the listed health problems, except in case of decreased vision and mental fatigue. We find out that identified respondents are exposed to high health risks. Interestingly, work characteristic, namely looking back when driving a forklift, has been confirmed by $63.5 \%$ of the respondents, but it does not correlate with any health problem, except with mental fatigue. In scientific literature authors frequently state looking back as key cause for occurrence of workrelated lower back pain, uneasiness, neck and muscular pains. The scientific literature also states that lower back pain is the main consequence of lifting from standing position, camying of heavy loads and situations in extreme conditions. The cause for our surprising result can be found in modem ergonomic solutions for forklift users, such as ergonomic seats, moveable commands and a like. $84.2 \%$ of respondents frequently walk between places where goods are taken. This work characteristic correlates with all proposed health problems, except with swelling of legs.

Thesis 2 assumes the existence of correlations between the type of means of transport used by the order picker and the degree of intensity of the observed type of health problem, which can be confimed by empirical research with $23.6 \%$. Survey identified approximately $50 \%$ of order pickers who use pallet trucks without ability to pallet and $39.7 \%$ of order pickers who frequently camy goods in their hands. Observed situation indicates high level of order pickers' physical activity. Survey revealed correlations between lower back pain and (1) use of pallet truck with possibility of personal transport, (2) use of pallet truck with possibility of lifting the order picker, and (3) use of order picking forklift. Those forklifts, when transporting loads, mostly require reversing and looking back by tuming head Similar findings are also confimed by scientific literature presented in the theoretical part. The findings are incompatible with observed correlations from the thesis 1 , where viewing back while driving does not correlate with any health problem, except with mental fatigue. We assume that the cause for described health problem is in inappropriate type of used forklift and lack of proper education for forklift operators.

Thesis 3 assumes that order picker's height of rate of the impact of a particular characteristic of his/hers work on his/hers health correlates with his/hers height of rate of the impact of a partic ular characteristic of his/hers work on the speed of his/hers work. Correlations can be fully confimed. The ergonomics of the workplace affects both the health status of order pickers and the work speed. From practice we know, that majority of managers still do not recognize ergonomics as factor that could help them to improve productivity. $63.5 \%$ of respondents report that they are not educated about ergonomics and the preservation of health. $87.3 \%$ of respondents report that daily program of recreational activities at workplaces is not allowed in their company. Managers often follow only legal requirements a nd do not act preventively (Gajšek et al., 2017):

- managers take into account only what is written in the laws;

- order pickers exposed to severe health risks should not be informed about possible measures for health protection, as this would disupt day-to-day work;

- huma nization of work is cost-related;

- improving working conditions does not inc rease profit.

\section{CONCLUSION}

The use of the term sustainable development in organizations has expanded into many areas of business over the past decade. It affects many logistic s activities, including storage. Beyond limiting the impact of organizations on the environment, an important part of sustainable development is an economic and social aspect (Gajšek, Đukić \& Opetuk, 2015). By reviewing the literature, we found that order-picking concept "picker-to-part" is an important and problematic area precisely 
because of economic and social influences. At the local level, the order-picking concept has on the one hand an influence on the order pickers from the health point of view and on the other hand, on the quality of the service provided by the company. Quality is diffic ult to define as a term that means the same for all servic es and products. It is important to understand the role of quality at different levels of organization and the various aspects from which it can be addressed. Therefore, the quality of the spectrum of definitions, which is usually, even in the case of picking, is related to costs (Koblar, 2010). During the review of existing quality definitions Piskar and Dolinšek concluded that (Koblar, 2010): "The quality of the product or service is often dependent on the price and the costs incurred during the use of the product or the provision of the service; Include people, tools and time." In this context, the use of factors that influence the level of ergonomics in picking is crucial in ensuring a quality service. One of the main reasons for the introduction and observance of ergonomic principles and the key problem on which businesses cannot influence is the aging of the population. Data on the aging of the population indicate a problem that will affect the business of the companies in the future. It is therefore important that companies provide to employees such work conditions under which they will be able to perform their work actively and reliably until retirement.

We believe that it would be interesting and meaning ful to expand the survey with a comparative analysis of productivity, frequency of errors and psychological impacts on order pickers in the order-pic king system, where ergonomic principles a re applied and introduced with a system where ergonomic principles are not taken into account. Ergonomics is a multidisciplinary discipline, therefore it is necessary to involve experts from various fields who can influence the development of their knowledge and research in order to fully assess the identification of ergonomic characteristic S.

On the basis of theory and research with the help of surveys, we found that compliance with ergonomic principles in the organization of order-picking work is insufficient. The effects of integrating ergonomics into the order-picking system in the literature are not given enough attention, which influences the recognition of the needs for introducing ergonomic principles into the picking process, the control of the current situation of the pickers working environment and the development of further ergonomic measures in order-picking. To summarize the findings from the field of researching the use of ergonomic principles in order-picking on the concept of spicker-topart « we found out that the ergonomic s of the workplace in order-picking:

- affects the quality of the service provided and consequently, the reputation of the company;

- affects the state of health of order pickers and consequently their produc tivity;

- affects the costs of the service, the cost of compensation payments, and other costs associated with order pickers' absence from work.

We conclude that taking into account ergonomic principles has a positive impact on working conditions that are directly reflected in the health status of order pickers and the quality of their work. In order to extend ergonomic principles and introduce them into the order-picking process, logistics managers need to recognize the purpose and importance of ergonomic s in the context of workplace, which is to create easy traceable steps in the work environment, resulting in fewer errors and a balance between the productivity of order pickers and the impact on their health which, with initial investments, has a long - term impact on cost reduction.

\section{REFERENCES}

De Koster, R., Le-Duc, T. \& Roodbergen, K. J. (2006). Design and Control of Warehouse Order Picking:a literature review. Nizozemska: Era smus School of Ec o nomic s

Definition and Domains of ergonomics [IEA] (b.d.). Najdeno 10. avgusta 2015 na spletnem naslovu http://www.iea.cc/whats/index.html

Gajšek, B., Vujic a, H.N., Butlewski, M. \& Đukić, G. (2017). Research opportunity: incorporation of human factors in order picking system models. Organizacja i Zarzadzanie 72, 45-61. DOI: 10.21008/j.02399415.2017.072.04.

Halilović, A. (2015) Določitev izhodišč za razvoj večnamenske delovne mize za potrebe sodobne logistike. Celje: Fa kulteta za logistiko

Izvajanje projekta »PROMO «s strani projektnega partneja SKEI [SKEI] (b.d.). Najdeno 7. maja 2016 na spletnem naslovu: http://skei.si/uploads/skei/public/_custom/PROMO.pdf 
Battini, D., Calza vara, M., Persona, A. \& Sgarbossa, F. (2015). Linking human availability and ergonomics parameters in order-picking system. IFAC-PapersO nLine 48(3), 345-35Sc ience direct: 94, str. 147-157. DOI: 10.1016/j.ifacol.2015.06.105.

Battini, D., Persona, A. \& Sgarbossa, F. (2014). A sustainable EOQ model: theoretical formulation and applications. Intemational Joumal of Production Economics 149, 145-153. DOI: https://d oi.org/10.1016/j.ijpe.2013.06.026.

Bokranz, R. \& Landau, K. (2006). Produktivitätsmanagement von Arbeitssystemen. MTM-Handbook. Stuttgart: Schäffer-Poeschel.

Christmanssona, M., Medbob, L, Hanssonc, G.A, Ohlssonc, K., Unge Bystromc, J., Mollerd, T. \& Forsman, M. (2002). A case study of a principally new way of materials kitting - an evaluation of time consumption and physic al workload. Intemational J oumal of Industrial Ergonomic s 30, 49-56.

De Koster, R., Le-Duc, T. \& Roodbergen, K.J . (2007). Design and control of wa rehouse order pic king: a literature review. European Joumal of Operational Research 182(2), 481-501. DOI: https://d oi.org/10.1016/j.ejor.2006.07.009.

European Agency for Safety and Health at Work (2010). European risk observatory reportEvropsko poročilo o tveganju. Luxembourg: Public ations Offic e of the European Union. DOI: 10.2802/ 10952.

Gajšek, B., Dukič, G. \& Opetuk, T. (2015). Review of ergonomic solutions to protect from injuries of lower back in c a se of forklifts drivers. In Mana gement of Technology - Step to Susta ina ble Production, 10.-11. J une 2015. Za greb: Croatian Assoc ia tion for PLM. Celje: Fac ulty of Logistics.

Stinson, M. (2014). Leaming Curves of Temporary Workers in Manual Order Picking Ac tivities. Log istics J oumal. Najdeno 7. junija 2016 na spletnem na slovu: Gajšek, B., Vujica Herzog, N., Butlewski, M. \& Đukić, G. (2017). Research opportunity: Incorporation of human factors in order picking system models. Organizacja $\mathrm{i}$ Zarzqdzanie 72. DOI: 10.21008/j.0239-9415.2017.072.04.

Goldscheid, C. (2008). Emittlung der Wirbelsäulenbelastung in manuellen Kommissioniersystemen. Dortmund: Technisc he Universität Dortmund.

Grilec, H. (2015). Ergonomic features of forklifts. Zagreb: FSB University of Zagreb.

Grosse, E.H., Glock, C.C.H. \& Neumann, W.P. (2015). Human Factors in Order Pic king System Design: A Content Analysis. IFAC-PapersO nLine 48(3), 320-325Science Direct, 48-3, str. 320-325. DOI: https://doi.org/10.1016/j.ifacol.2015.06.101.

Günthner, W. A., Deuse, J., Rammelmeier, T. \& Weisner, K. (2014). Entwicklung und technische Integration einer Bewertungsmethodik zur Emittlung von Mitarbeiterbelastungen in Kommissioniersystemen (ErgoKom). München: Technische Universität.

Hompel, T.M., Sadowsky, V. \& Beck, M. (2011). Kommissionierung: Materialflusssysteme 2 - Planung und Berechnung der Kommissionierung in der Logistik. Berlin: Springer.

Koblar, M. (2010). Quality Management kakovosti. In 7th Festival of Economics and Management Research, Zbomik 7. festivala raziskovanja ekonomije in managementa (str. 295). Koper: Faculty of management, University of Primorska. Fakulteta za management.

Marras W.S., Da vis, K.G., Kirking, B.C. \& Bertsc he, P.K. (1999). A comprehensive a nalysis of low-back disorder risk and spinal loading during the transfering and repositioning of patients using different techniques. Ergonomics 42(7), 904-26. DOI: 10.1080/001401399185207.

Motmans R. (2012). Reducing whole body vibration in forklift drivers. Work 41, Suppl 1:2476-81. DOI: 10.3233/WOR-2012-0484-2476.

Napolitano, M. (2012). 2012 warehouse/DC operations survey: Mixed signals. Modem Materials Handling 51(11), 48-56.

Punnett, L \& Wegman, D.H. (2004). Work-related musculoskeletal disorders: the epidemiologic evidence and the debate. Joumal of Electromyography and Kinesiology 14(1), 1323.

Richards, G. (2011). Warehouse Management: A complete guide to improving efficiency and minimizing costs in the modem warehouse. London: Kogan Page Publishers.

Sambt, J. (2014, April, 1. a pril). What is the demographic forecast for Slovenia in 10 or 20 years? Retrieved J uly 3, 2017, from Kakšna je demografska napoved za Slovenijo čez 10 oziroma 20 leł? Delo. Najdeno 5. april 2017 na spletnem naslovu http://www.delo.si/druzba/delova-borza-dela/kaksna-je-demografskanapoved-za-slovenijo-cez-10-oziroma-20-let.html

Schneider, E. \& Irastorza, X. (2010). Work-Related Musculoskeletal Disorders in the EU. Luxembourg: Publications Office of the European Union.

Tompkins, J.A., White, Y.A., Bozer, E.H. \& Tanchoco. J.M.A. (2010). Facilities Planning (4th ed.). Hoboken, NJ: Wiley.

\section{AUTHORS}

A. Nina Labus, Msc., (e-ma il: nina .la bus@hotmail.com).

B. Brigita Gajšek, Phd, University of Ma ribor, Celje, Slovenia (e-ma il: brigita.gajsek@um.si). 